\title{
Chinese overseas industrial parks in Southeast Asia: An examination of policy mobility from the perspective of embeddedness
}

SONG Tao ${ }^{1,2}$, LIU Weidong ${ }^{1,3}$, LIU Zhigao ${ }^{1,3}$, WUZHATI Yeerken ${ }^{1}$

1. Institute of Geographic Sciences and Natural Resource Research, CAS, Beijing 100101, China;

2. The Collaborative Innovation Center of the Geographical Environment and Frontier Development in Southwest China, Kunming 650500, China;

3. College of Resources and Environment, University of Chinese Academy of Sciences, Beijing 100049, China

\begin{abstract}
The development of overseas industrial parks is a key component of the Belt and Road Initiative and an expected experimental way of promoting inclusive globalization by inventing new forms of cooperation between China and local host countries. Policy mobility, a classic theory within international political geography addressing the connection between local and global policies, has implications for overseas industrial parks development. In this paper, we argue that policies are not easily moved directly from one place to another; instead, policies are embedded due to the role of local actors in policy mobility. This article first provides an overview of seven China-Southeast Asia economic and trade cooperation zones identified by the Ministry of Commerce, and analyzes their key participants. It then discusses policy mobility by looking into the roles of revenue, land, and talent in developing these industrial parks. The paper finds that these parks face challenges, such as the complicated geographical environments of host countries, huge pressure from enterprise investment capital, the lack of overseas service platforms, and underdeveloped agglomeration economies. In the light of the current situation, policy suggestions for the future sustainable development of overseas industrial parks are put forward.
\end{abstract}

Keywords: overseas industrial parks; Southeast Asia; Belt and Road Initiative; inclusive globalization; policy mobility; China

\section{Introduction}

In the context of neoliberal globalization, regional or urban decision makers have selected optimal paths to accelerate local development, embracing special designations such as "smart city", "green city" and "vitality." Recently, a great deal of attention has been paid to

Received: 2018-01-05 Accepted: 2018-03-20

Foundation: National Natural Science Foundation of China, No.41701131, No.41701138, No.41530751; National Social Science Foundation of China, No.17VDL008

Author: Song Tao (1983-), PhD, specialized in regional sustainable development and globalization.

E-mail: songtao@igsnrr.ac.cn

*Corresponding author: Wuzhati Yeerken, PhD, E-mail: yeek@igsnrr.ac.cn 
the concept of "policy mobility" in geography, politics, and economics (Temenos and McCann, 2013). Policy mobility refers to the migration, combination, and evolution of policies, valuations, and ideas from one region to another. In this process, countries, regions, and enterprises learn, integrate, choose, and implement specific policies to facilitate regional business development, environmental protection, and education (Fraser, 2003). Non-Chinese political geographers use this concept to investigate policies for smart cities, historically and culturally distinctive areas, and urban rustbelts. In the era of neoliberalism, policy borrowing has played an important role in driving development.

In the context of a changing world situation the Central Committee of the Communist Party of China and the State Council put forward the Belt and Road Initiative (BRI) as the template for the general opening-up of China in a new era of global development (Hudson, 2016; Liu, 2015; Liu and Dunford, 2016). Overseas industrial parks, as a spatial carrier for implementing the BRI, play a vital role in China's pursuit of an alternative globalization path. Since the end of 2005, the Ministry of Commerce has unveiled a series of policies to encourage the development of economic and trade cooperation zones in foreign countries, referred to as "jointly going out". After the 2008 global financial crisis, faced with the weak global economy and downturn in international market demand, many Chinese enterprises began to "go out" with the help of encouraging policies, such as Essential Requirements and Application Process for Overseas Economic and Trade Cooperation Zones of China (Ministry of Commerce, 2006) and Opinion on the Agreement for the Promotion of the Construction of Overseas Economic and Trade Cooperation Zones (State Council, 2008). Outward direct foreign investment and the number of overseas industrial parks have increased rapidly. Countries along the Belt and Road (B\&R), particularly those in Southeast Asia, have become an important destination for these Chinese overseas investments. By the end of 2016, China had built 56 overseas economic and trade cooperation zones in 20 BRI countries, attracting 1,082 enterprises with a cumulative investment value of 18.55 billion US dollars and a gross output value of 50.69 billion US dollars. Together, these BRI zones accounted for $72.72 \%$ of all Chinese cooperation zones, $71.09 \%$ of the enterprises in all zones, $76.68 \%$ of the cumulative investment value, and $72.13 \%$ of the gross output value. Clearly, the development of overseas industrial parks is a significant spatial driver promoting the five connectivities proposed by BRI, i.e., policy coordination, facilities connectivity, unimpeded trade, financial integration and people-to-people bonds, as well as for the development of host countries.

China's BRI embodies a new model of "inclusive globalization" distinct from neoliberal globalization (Liu, 2017). The BRI rests on the idea that there is not one optimal path for development, i.e., that followed by developed countries and proposed/imposed by international institutions such as the World Bank, and that every country ought to select a path that suits its own development conditions and environment (Liu, 2017). The development of overseas industrial parks must conform with the principles of inclusive globalization. Existing research on industrial zones and overseas industrial parks has paid more attention to profit-driven accumulation of capital and external control in the context of neoliberal globalization. In contrast, the BRI draws on Chinese characteristics and attaches importance to willing participation and mutual advantage (including resident benefits and local and national development) through policy mobility and the enhancement of interconnectivity. And yet little research has investigated these developments in the context of inclusive globalization.

The purpose of this paper is therefore to use case-study evidence to deepen our under- 
standing of how actors act globally to construct Chinese overseas industrial parks in Southeast Asia in the context of inclusive globalization and, in this way, contribute to political and geographical theory. As already mentioned, it examines 'policy mobility' which refers to the ways in which policy knowledge and policy models move from one place to another place. In doing so, it addresses three recent critical developments in the policy mobility literature. First, Peck and Theodore (2010) have argued that the 'policy mobility' literature has focused too narrowly on the transmitting best (or better) practices, instead of best 'fit' practices (Liu, 2017) embedded in a field of adaptive connections, deeply structured by enduring power relations and shifting ideological alignments. Second, Larner (2003) has emphasized the paucity of knowledge about who mobilizes policies, and argues for more awareness about policy actor networks, including national state actors, local officials, civilians and Non-governmental organizations (Inverardi-Ferri, 2017). Third, the narrow definition of 'neoliberal global-ness' in some of the global cities literature has been criticised (McCann, 2004). An analysis of policies contributing to 'inclusive global-ness' policy and of Chinese overseas industrial park policies enriches the concepts of policy mobility and inclusive globalization.

The argument is composed of two parts. First, best (or better) practices should be seen as best 'fit' policies (Liu, 2017) deeply structured by both complex foreign and home power relations in the context of 'inclusive globalization'. Policy formation and transformation are visualized as (socially) constructed processes and fields of power embedded in their local environments, and are not reduced to a more-or-less efficient process for transmitting best (or better) practices (Peck and Theodore, 2010). Second, national state actors operate as active agents of policy mobility, especially in politico-economic contexts characterized by centralized governance. At the same time, the roles of leading enterprises and cooperative enterprises, local governments, local residents and non-governmental organizations should never be neglected and all deserve more sustained analysis for a better conception of 'embeddedness', that is to say how enterprise agendas and relationship networks shape their role as policy mobility agents. These insights will shed light on inclusive globalization dynamics during a period when policies and their authors seem to be learned and adapted to local development.

In this paper, the analytical framework combines the study of policy mobility with the concept of 'embeddedness' in the construction of overseas industrial parks. From the perspective of political geography and the concept of policy mobility, this study identifies the governance structure of host countries and the identity of key participants in constructing Chinese overseas industrial parks in Southeast Asia, demonstrates how they are embedded and identifies the challenges of mobilizing policies for these parks. Suggestions regarding future development in a context of inclusive globalization are proposed. All will enrich the research on the BRI, policy mobility, and overseas industrial parks.

The research drew on interviews and qualitative analysis. Data and resources were collected from the B\&R construction conferences organized by China's Council for the Promotion of International Trade (CCPIT), development demands, and suggestions to the CCPIT and Chamber of Commerce. Face-to-face and telephone interviews were conducted with overseas industrial parks, enterprises, and financial institutions, focusing on the current state of overseas investment, factors constraining overseas programs, the roles that government and social institutions play, existing problems, the demands for enterprises to expand inter- 
nationally, and suggestions relating to B\&R construction. The interviewees included Southeast Asia overseas industrial parks, such as the Thai-China Industrial Park in Rayong and the Long Giang Industrial Park in Vietnam, financial institutions, such as the China-Africa Fund, the Industrial and Commercial Bank of China, the China Investment Corporation, HSBC, the China Development Bank, and many internationally expanding enterprises, such as the China Communications Construction Company Limited, China Non-Ferrous Metal Corporation, Ormosia Group, and Tsinghua Science Park.

This paper is organized into four sections. The first section introduces the Chinese overseas industrial parks in Southeast Asia. The second section examines the role of policy mobility and the degrees of embeddedness of overseas industrial parks. The third section systematically analyzes the governance structure and key participants in Chinese overseas industrial parks in Southeast Asia, and shows that the state played the "regulator" role, coordinated with local government, and ensured that all parties equally participate in developing industrial parks. Finally, the "policy set" for Chinese overseas industrial parks in Southeast Asia is examined and the challenges of "policy mobility" in their development are identified.

\section{Overseas industrial parks: policy mobility and embeddedness}

Policy mobility is frequently examined in political geography, where it examines the assembling, transferring, and mutating of policies as they move from one location to another. Scholars specializing in this discipline have advanced our understanding of the multiple scales of policy mobility, moving beyond spatial binaries such as global-local and far-near. The relationship networks between global, national, and local factors shape policy dynamics. Social interaction in hotels, stations, convention centers, resorts, galleries, and global cities will accelerate policy sharing (Cook and Ward, 2012). Regional or urban models that "perform better" whether they relate to business, culture, transport, education, or other aspects of life give rise to policy mobility. Elements of policy models, such as capital, policy regimes, taxes, and technical abilities affect the adoption of a specific policy model in other places. In this process, elements of these policies tend to be "collective," assembled collectively in a policy zone (Larner and Laurie, 2010; McCann, 2011). Generally, policy mobility should be recognized as the dynamic process of transferring, incubating, and mutating policies across boundaries (Allen and Cochrane, 2007). A significant and growing literature dealing with these issues adopts a post-structuralist approach, examining the 'assemblage' of calculative practices and knowledge involved in the transfer, adoption and reception of policy ideas (Allen and Cochrane, 2007; McCann 2011). This approach affords insights into the travels, learning and mutation of particular policies in case studies set in particular politico-economic contexts and the 'institutional geometries' (Brenner et al., 2010), improves the understanding of how 'the actions and choices of one [state] affect another' (Elkins and Simmons, 2005) and has been widely applied in research into development, commercial, industrial, and other zones with "policy set" characteristics (Geddie, 2015).

China has witnessed turbulent spatial economic changes since the start of opening and reform in the early 1980s. In an international context shaped by neoliberal globalization, the exploration of regional spatial production strategies such as new districts, new zones and overseas industrial parks has developed gradually and regarded in China as having 'Chinese characteristics'. The 'territorial space' associated with the dynamics of economic growth is 
seen as shaped by specificities of land control, capital investment, personnel and governance structures embracing policies, power and leadership elements (Rithmire, 2013; Liu and Ye, 2015). Especially since the implementation of the BRI, overseas industrial parks have played a key role in expanding the economic space and governance fields for both home and host countries with an emphasis upon equal opportunities for stakeholders to participate in and benefit from the protection of cultural diversity.

The macroeconomic and institutional replication mechanisms and internal logic of the overseas special economic zones differ from those at home making it necessary to characterize the differing state-local hierarchy relationships and other key differentiating factors. The "state" in particular is a key factor playing a predominant role in administrative instruction, knowledge dissemination, and integrated management at different scales. Since reform and opening up, China's regional governance structure has had state-led development characteristics. In spite of market reform, Chinese governments continue to exert strong control (Ye, 2014). Strong national governance of Chinese long-term economic growth (Acemoglu et al., 2005), which has resulted in the leapfrog development of Chinese "zones" makes the Chinese model a mixed economy system in which the state plays a leading role. The rise of China is an important case of latecomer advantage that reflects the importance of the grounding of economic models in supportive and capable institutional configurations (Michael, 2017).

At the same time, "policy mobility" is embedded in "places" as shown in Figure 1. Local policy makers, NGOs, residents and other participants also profoundly influence policy (England and Ward, 2007). Therefore, China's going out involves an intertwining of globalization, state, and place.

Domestically, the central government promotes China's global competitiveness by constructing enterprise cities (Jessop et al., 1999), characterized by strong urban entrepreneurship. Global city regions, such as the Pearl River Delta and Yangtze River Delta, are examples of areas where an entrepreneurial spirit promotes China's economic growth. In China much of the responsibility to promote local economic development lay with local governments which in the context of a cadre responsibility system that prioritized GDP growth and lacking financial resources after the 1994 reform of tax sharing system pursued land-value appreciation and industry-driven development models (Lin, 2001; Xu and Yeh, 2005; Zhang, 2006; Yeh et al., 2014). The driving forces of China's economic zones have been widely studied but there is a question as to whether and if so how any of these roles and driving forces apply to Chinese overseas industrial parks. This question requires further exploration. Furthermore, the policy mobility literature tends to downplay the fundamentally social-practical, interpersonal and institutionally embedded, yet fluid and processual - character of policy making in host countries (Peck and Theodore, 2001). All of these issues require consideration when examining industrial parks in the complex geopolitical, institutional, political context of Southeast Asia.

One of the core issues for policy mobility research on overseas industrial parks is the role of the embeddedness of transferred policy experiences in driving successful implementation. Embeddedness refers to the ways in which leading enterprises seek out localized assets and incorporate them into their own activities when establishing plants in Chinese overseas industrial parks. Shaped by the regulatory practices of states and in particular by the aim of a 
host state to embed transnational economic activities as strongly as possible in the local/national economy (Liu and Dicken, 2006), these processes are also shaped by other key actors such as local governments, local residents and non-governmental organizations.

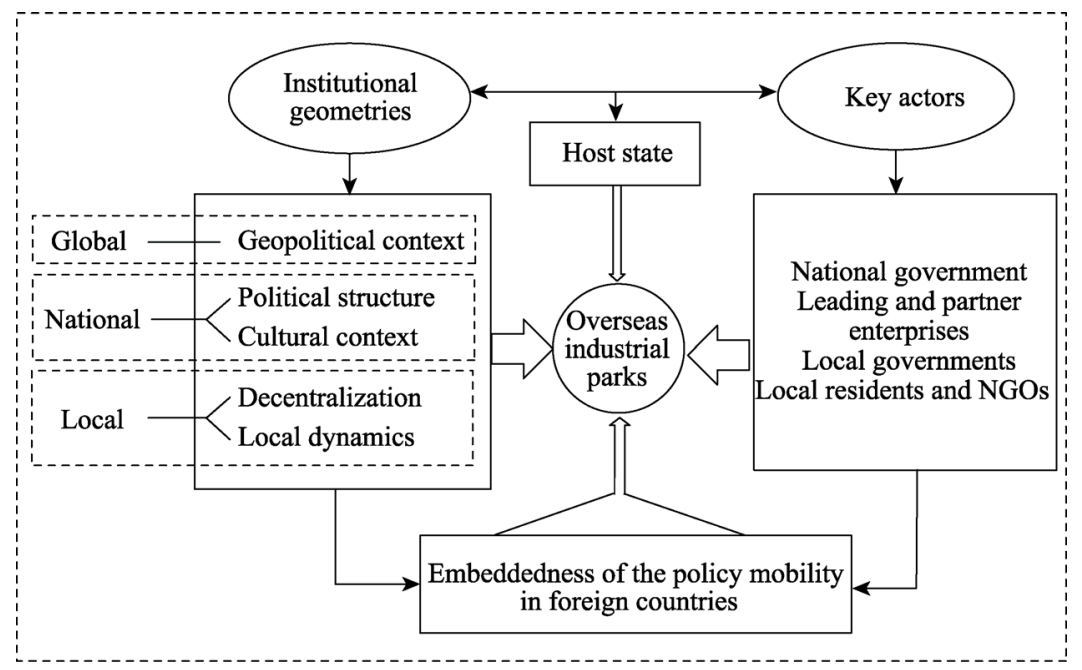

Figure 1 The conceptual framework of policy mobility and embeddedness for overseas industrial parks

In the specific context of the Chinese overseas industrial parks in Southeast Asia studied in this paper, embeddedness relates to the degrees of involvement of leading and cooperative enterprises, host governments, local residents and non-governmental organizations in projects designed to attract capital and technology to produce goods and services through insertion into global production networks in an intensely competitive global environment (Liu and Dicken, 2006). All of these actors attempt to achieve these objectives on terms most favorable to their own aspirations. In terms of these respective aspirations, and the strategies through which they are pursued, all actors are locked into n-actor bargaining processes which unfold in the context of the evolving institutional geometries of host countries.

\section{Policy mobility and Chinese overseas industrial parks in Southeast Asia}

\subsection{Overview of overseas industrial parks in Southeast Asia}

In recent years, the trade and investment between members of the China-Association of Southeast Asian Nations (ASEAN) group have increased rapidly. By 2016, China had been the largest trade partner of the ASEAN for seven successive years, while ASEAN had been the third largest trade partner of China for five consecutive years. Southeast Asia had the largest share of Chinese direct investment in the BRI countries. In 2015, the cumulative stock of Chinese direct investment in Southeast Asia reached 62.82 billion US dollars, accounting for $54.3 \%$ of the total stock of B\&R investments. Chinese enterprises began building overseas industrial parks in the 1990s. For example, the Haier Group constructed an industrial park in Camden, South Carolina, USA, in 1999. However, the first Chinese overseas industrial park in Southeast Asia was built in the 21st century. In 2005, the Rayong Thai-China Industrial Park in Thailand was established by the Huali Industrial Group. In 2016, 20 overseas cooperation zones were approved by the Ministry of Commerce (Tables 
2-3), of which seven were located in Southeast Asian countries along the B\&R, i.e., Thailand, Cambodia, Vietnam, Laos, and Indonesia (Figure 2 and Table 1).

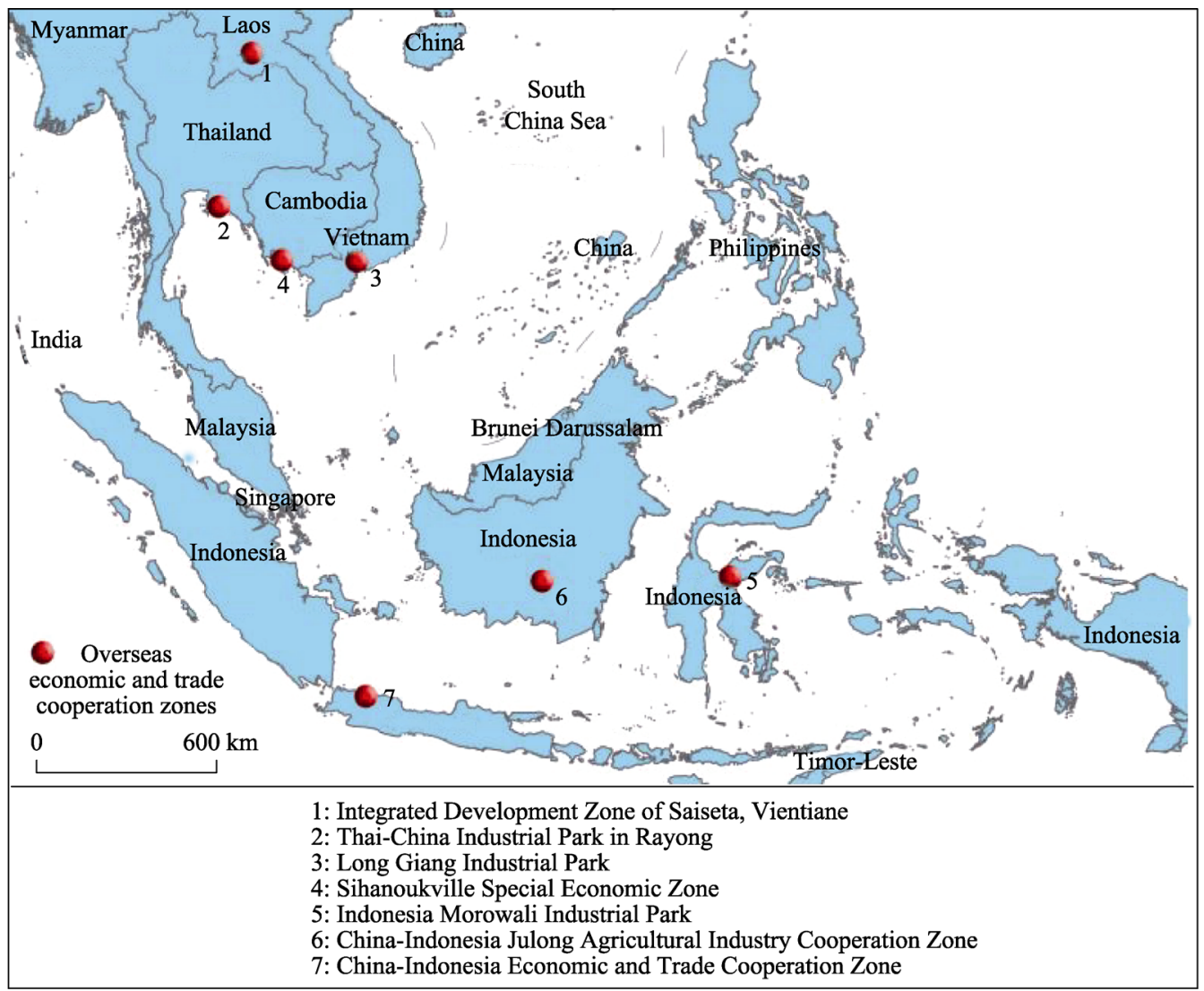

Figure 2 The locations of Chinese overseas economic and trade cooperation zones in Southeast Asia

Table 1 The profiles of seven Chinese overseas economic and trade cooperation zones in Southeast Asia approved by the Chinese Ministry of Commerce

\begin{tabular}{|c|c|c|c|c|}
\hline Cooperation zone & $\begin{array}{l}\text { Year of es- } \\
\text { tablishment }\end{array}$ & Country & Chinese enterprises & Location \\
\hline $\begin{array}{l}\text { Thai-China } \\
\text { Industrial Park } \\
\text { in Rayong }\end{array}$ & 2005 & Thailand & $\begin{array}{l}\text { Huali Industrial } \\
\text { Group }\end{array}$ & $\begin{array}{l}\text { Located near the No. } 331 \text { High-speed } \\
\text { Railway, Rayong Province, } 27 \mathrm{~km} \\
\text { from Laem Chabang, the largest deep } \\
\text { water port in Thailand }\end{array}$ \\
\hline $\begin{array}{l}\text { Sihanoukville } \\
\text { Special Economic } \\
\text { Zone }\end{array}$ & 2006 & Cambodia & $\begin{array}{l}\text { Jiangsu Taihu Cam- } \\
\text { bodia International } \\
\text { Economic Coopera- } \\
\text { tion Zone Invest- } \\
\text { ment Co. LTD }\end{array}$ & $\begin{array}{l}\text { Located in Sihanoukville, the only } \\
\text { international port city in Cambodia, } 3 \\
\mathrm{~km} \text { from Sihanoukville International } \\
\text { Airport and } 12 \mathrm{~km} \text { from the port }\end{array}$ \\
\hline $\begin{array}{l}\text { Long Giang } \\
\text { Industrial Park }\end{array}$ & 2007 & Vietnam & $\begin{array}{l}\text { Tien Giang Invest- } \\
\text { ment Management } \\
\text { Co. LTD }\end{array}$ & $\begin{array}{l}\text { Located in the Jiulongjiang Plain, } \\
\text { southern Vietnam. About } 50 \mathrm{~km} \text { from } \\
\text { downtown Ho Chi Minh City, the } \\
\text { international airport, and Saigon Port. } \\
\text { The park is near an inland river and the } \\
\text { cargo can be transported directly to the } \\
\text { international port. }\end{array}$ \\
\hline
\end{tabular}


(Continued)

\begin{tabular}{|c|c|c|c|c|}
\hline Cooperation zone & $\begin{array}{l}\text { Year of es- } \\
\text { tablishment }\end{array}$ & Country & Chinese enterprises & Location \\
\hline $\begin{array}{l}\text { China-Indonesia } \\
\text { Economic and Trade } \\
\text { Cooperation Zone }\end{array}$ & 2007 & Indonesia & $\begin{array}{l}\text { Guangxi State } \\
\text { Farms Group LTD }\end{array}$ & $\begin{array}{l}\text { Located in the Greenland International } \\
\text { Industry Center, Bekasi County, east of } \\
\text { Jakarta, the capital of Indonesia }\end{array}$ \\
\hline $\begin{array}{l}\text { Integrated devel- } \\
\text { opment zone of } \\
\text { Saiseta, Vientiane }\end{array}$ & 2010 & Laos & $\begin{array}{l}\text { Yunnan Provincial } \\
\text { Overseas Invest- } \\
\text { ment Co., Ltd }\end{array}$ & $\begin{array}{l}\text { Located in Saiseta and Saitani counties, } \\
\text { in the northeastern part of Vientiane, } \\
\text { the capital of Laos, with an area of } 10 \\
\mathrm{~km}^{2}\end{array}$ \\
\hline $\begin{array}{l}\text { Indonesia } \\
\text { Morowali Indus- } \\
\text { trial Park }\end{array}$ & 2013 & Indonesia & $\begin{array}{l}\text { Shanghai Decent } \\
\text { Investment Group }\end{array}$ & $\begin{array}{l}\text { Located in Morowali County, Central } \\
\text { Sulawesi, Indonesia, with an area of } \\
>2,000 \text { ha. It is located next to the } \\
\text { provincial highway, about } 60 \mathrm{~km} \text { from } \\
\text { the center of Morowali County }\end{array}$ \\
\hline $\begin{array}{l}\text { China-Indonesia } \\
\text { Julong Agricultural } \\
\text { Industry Coopera- } \\
\text { tion Zone }\end{array}$ & 2011 & Indonesia & $\begin{array}{l}\text { Tianjin Julong } \\
\text { Group }\end{array}$ & $\begin{array}{l}\text { Many parks in the same area, including } \\
\text { Central Kalimantan Park, Southern } \\
\text { Kalimantan Park, Western Kalimantan } \\
\text { Park, and Northern Kalimantan Park in } \\
\text { Kalimantan Island as well as Lampung } \\
\text { Port Park, Lampung Province in Sumatra }\end{array}$ \\
\hline
\end{tabular}

Chinese investment in Southeast Asia is mainly concentrated in Indonesia, Cambodia, and Thailand, with extensive cooperation in mining, engineering machinery, agriculture, and construction (Table 2). Overseas industrial parks directed at infrastructure industries, such as the Sihanoukville Special Economic Zone, are mainly built in areas with an industrial economy and excellent supporting facilities; labor-intensive overseas industrial parks, such as Long Giang Industrial Park, are established in areas with rich labor resources; overseas industrial parks developed with energy resources, such as Indonesia Morowali Industrial Park, are constructed near ports and areas rich in energy resources; agricultural industrial cooperation zones, such as the China-Indonesia Julong Agricultural Industry Cooperation Zone, rely on superior natural conditions and an agriculture based economy. At present, Chinese overseas industrial parks in Southeast Asia are characterized by diversification and

Table 2 Leading industries and enterprises in China-Southeast Asia economic and trade cooperation zones

\begin{tabular}{|c|c|c|c|c|c|}
\hline $\begin{array}{c}\text { Cooperation } \\
\text { zone }\end{array}$ & Area $\left(\mathrm{km}^{2}\right)$ & Description & $\begin{array}{l}\text { Leading } \\
\text { industry }\end{array}$ & $\begin{array}{c}\text { Investment/ } \\
\text { income }\end{array}$ & $\begin{array}{c}\text { Main enter- } \\
\text { prises }\end{array}$ \\
\hline $\begin{array}{l}\text { Thai-China } \\
\text { Industrial Park } \\
\text { in Rayong }\end{array}$ & $\begin{array}{l}12 \\
\text { 1st installment: } 1.5 \text {; } \\
\text { 2nd installment: } \\
2.5 \text {; } \\
\text { 3rd installment: } 8\end{array}$ & $\begin{array}{l}\text { Industrial areas, bonded } \\
\text { areas, convention and } \\
\text { exhibition center, logis- } \\
\text { tics bases and commer- } \\
\text { cial and residential } \\
\text { support facilities }\end{array}$ & $\begin{array}{l}\text { Automobile } \\
\text { fittings, } \\
\text { machinery } \\
\text { and home } \\
\text { appliances }\end{array}$ & $\begin{array}{l}1 \text { billion US } \\
\text { dollars } \\
(2016)\end{array}$ & 80 enterprises \\
\hline $\begin{array}{l}\text { Sihanoukville } \\
\text { Special Eco- } \\
\text { nomic Zone }\end{array}$ & $\begin{array}{l}11.13 \\
1 \text { st installment: } \\
5.68\end{array}$ & $\begin{array}{l}\text { Textile and apparel, } \\
\text { hardware tools, and light } \\
\text { industrial appliances in } \\
\text { export processing, com- } \\
\text { mercial and trade, and } \\
\text { residential zones }\end{array}$ & $\begin{array}{l}\text { Textile and } \\
\text { apparel, } \\
\text { hardware } \\
\text { tools, light } \\
\text { industrial } \\
\text { appliances }\end{array}$ & $\begin{array}{l}\text { Investment } \\
\text { value of } 0.31 \\
\text { billion US } \\
\text { dollars }\end{array}$ & $\begin{array}{l}100 \text { enterprises, } \\
\text { including } \\
\text { Jinchenyuan } \\
\text { Textile Co. } \\
\text { LTD, Enterex } \\
\text { International } \\
\text { Limited (auto- } \\
\text { mobile fittings), } \\
\text { and Canadia } \\
\text { Bank }\end{array}$ \\
\hline
\end{tabular}


(Continued)

\begin{tabular}{|c|c|c|c|c|c|}
\hline $\begin{array}{c}\text { Cooperation } \\
\text { zone }\end{array}$ & Area $\left(\mathrm{km}^{2}\right)$ & Description & $\begin{array}{l}\text { Leading in- } \\
\text { dustry }\end{array}$ & $\begin{array}{c}\text { Investment/ } \\
\text { income }\end{array}$ & $\begin{array}{l}\text { Main enter- } \\
\text { prises }\end{array}$ \\
\hline $\begin{array}{l}\text { Long Giang } \\
\text { Industrial } \\
\text { Park }\end{array}$ & $\begin{array}{l}6 \\
\text { industrial district: } \\
5.4 ; \\
\text { residence area: } 0.6\end{array}$ & $\begin{array}{l}\text { Industrial district; } \\
\text { residence area }\end{array}$ & $\begin{array}{l}\text { Textile and } \\
\text { light industry, } \\
\text { machinery and } \\
\text { electronics, } \\
\text { and chemical } \\
\text { construction } \\
\text { materials }\end{array}$ & $\begin{array}{l}\text { With the } \\
\text { income of } \\
0.4 \text { billion } \\
\text { US dollars } \\
(2014)\end{array}$ & $\begin{array}{l}17 \text { established } \\
\text { and under con- } \\
\text { struction enter- } \\
\text { prises in } 2015 \text {; } \\
13 \text { enterprises } \\
\text { came into ser- } \\
\text { vice in the same } \\
\text { year }\end{array}$ \\
\hline $\begin{array}{l}\text { China- } \\
\text { Indonesia } \\
\text { Economic } \\
\text { and Trade } \\
\text { Cooperation } \\
\text { Zone }\end{array}$ & $\begin{array}{l}5 \\
1 \text { st installment: } \\
2.05\end{array}$ & $\begin{array}{l}3 \text { industries in a } \\
\text { group, including } \\
\text { household appliances, } \\
\text { machinery manufac- } \\
\text { turing, and agricul- } \\
\text { tural processing }\end{array}$ & $\begin{array}{l}\text { Automobile } \\
\text { assembly, } \\
\text { machinery, } \\
\text { home appli- } \\
\text { ances, fine } \\
\text { chemicals, } \\
\text { and new ma- } \\
\text { terials }\end{array}$ & $\begin{array}{l}\text { Investment } \\
\text { value of } 0.65 \\
\text { billion US } \\
\text { dollars }\end{array}$ & $\begin{array}{l}\text { In } 2015,25 \\
\text { enterprises and } \\
12 \text { under con- } \\
\text { struction }\end{array}$ \\
\hline $\begin{array}{l}\text { Integrated } \\
\text { development } \\
\text { zone of } \\
\text { Saiseta, } \\
\text { Vientiane }\end{array}$ & 10 & $\begin{array}{l}\text { Agricultural products } \\
\text { export and processing, } \\
\text { light industrial prod- } \\
\text { ucts export and proc- } \\
\text { essing, services and } \\
\text { logistics, bonded area, } \\
\text { business district and } \\
\text { residence, and tourist } \\
\text { area }\end{array}$ & $\begin{array}{l}\text { Energy and } \\
\text { chemical } \\
\text { industry, } \\
\text { agricultural } \\
\text { and animal } \\
\text { products, } \\
\text { electric prod- } \\
\text { ucts industry, } \\
\text { cigarettes and } \\
\text { tobacco, con- } \\
\text { struction } \\
\text { materials, and } \\
\text { logistics and } \\
\text { storage }\end{array}$ & $\begin{array}{l}\text { Investment } \\
\text { value of } 0.3 \\
\text { billion US } \\
\text { dollars }\end{array}$ & 13 enterprises \\
\hline $\begin{array}{l}\text { Indonesia } \\
\text { Morowali } \\
\text { Industrial } \\
\text { Park }\end{array}$ & 20 (plan) & $\begin{array}{l}4 \text { electronic genera- } \\
\text { tors, base station, } \\
\text { satellite television } \\
\text { system, } 300,000 \text { tons } \\
\text { port berth and more } \\
\text { than } 70 \text { residences }\end{array}$ & $\begin{array}{l}\text { Ferronickel, } \\
\text { stainless steel }\end{array}$ & $\begin{array}{l}\text { Total in- } \\
\text { vestment } \\
\text { value of } 4 \\
\text { billion US } \\
\text { dollars }\end{array}$ & $\begin{array}{l}6 \text { enterprises, } \\
\text { including PT } \\
\text { Sulawesi Min- } \\
\text { ing Investment } \\
\text { and Indonesia } \\
\text { Guangqing } \\
\text { Ferronickel } \\
\text { Industry Co. } \\
\text { LTD }\end{array}$ \\
\hline $\begin{array}{l}\text { China- } \\
\text { Indonesia } \\
\text { Julong Agri- } \\
\text { cultural In- } \\
\text { dustry } \\
\text { Cooperation } \\
\text { Zone }\end{array}$ & 4.21 & $\begin{array}{l}5 \text { parks including } \\
\text { Central Kalimantan } \\
\text { Park, Southern Kali- } \\
\text { mantan Park, Western } \\
\text { Kalimantan Park, and } \\
\text { Northern Kalimantan } \\
\text { Park in the Kaliman- } \\
\text { tan Island and the } \\
\text { Lampung Port Park, } \\
\text { Lampung Province in } \\
\text { Sumatra }\end{array}$ & $\begin{array}{l}\text { Oil palm } \\
\text { planting and } \\
\text { development, } \\
\text { intensive } \\
\text { processing, } \\
\text { acquisition, } \\
\text { storage and } \\
\text { logistics }\end{array}$ & $\begin{array}{l}\text { A total in- } \\
\text { vestment of } \\
1.245 \text { billion } \\
\text { US dollars }\end{array}$ & $\begin{array}{l}12 \text { upstream } \\
\text { and down- } \\
\text { stream enter- } \\
\text { prises for palm } \\
\text { oil }\end{array}$ \\
\hline
\end{tabular}

optimization, with investments transitioning from traditional fields, such as energy, mining, construction and contract engineering, to frontier fields, such as new energy, manufacturing, commercial services, and scientific cooperation with platforms for logistics parks and special economic zones. 


\subsection{Institutional geometries of host countries for overseas industrial parks in South- east Asia}

A critical element of the policy mobility process is embedding it in the conventions, rules, and institutions which form the environment in which the firms in industrial parks must operate. In the cases of Chinese overseas industrial parks in Southeast Asia, this institutional context is extremely complex, not to say mysteriously opaque. Here we briefly outline four key specific dimensions of the complex sociopolitical environment in Southeast Asia: the geopolitical context; the political structure; the cultural context; and trends in the decentralization of central state power.

\subsubsection{Geopolitical context}

Southeast Asian countries have for a long time formed a crucially important region in world politics, and, at the same time, have been pawns in colonial and geopolitical clashes among extra regional superpowers, such as Europe, the United States and Japan. Southeast Asian countries were mostly colonized by Holland, Portugal, Britain, France, Japan and the United States. Their political systems and geopolitical culture were deeply influenced by colonial countries, sometimes retaining strong social and cultural adherence to former colonial countries. In the aftermath of $9 / 11$, especially with the rise of China and in a context of relative US economic decline and foreign policy adventurism, there was stronger US engagement with Southeast Asia. The Obama administration decided to arrest regional strategic drift with a 'pivot' towards the Asia - Pacific. The Trump administration decided to focus more on the idea of the Indo-Pacific, attaching importance to the signing of bilateral trade and cooperation agreements with Japan and India. The US has drawn on interpretations of complex and globalized conflicts - especially surrounding perceptions of militant Islam - to legitimize US interventions in Southeast Asian states. An outcome is rising competitions amongst superpowers in infrastructure construction including industrial parks in a geopolitical term, "shattered area" (Song et al., 2016).

\subsubsection{Political structure}

In political terms the 11 countries in Southeast Asia are diverse. Vietnam and Laos are the only socialist states, implementing a people's representative system and one party leadership of the Communist Party. Four countries are monarchies: Thailand, Cambodia and Malaysia are constitutional monarchies and Brunei is an absolute monarchy. Singapore and East Timor are parliamentary republics, while Indonesia, the Philippines and Myanmar are the presidential republics. In general, in situations in which there are diverse mechanisms through which the main party or political leader controls government leaders and governs socio-economic development, advancing the cause of Chinese overseas industrial parks involves identifying powerful units with strong bargaining power.

\subsubsection{Cultural context}

As for the cultural context, Southeast Asian states are ethnically diverse, and have been influenced for a long time by Indian, Arabian, Chinese and Western culture, giving rise to a variety of cultural systems and religious beliefs. In terms of religion, Myanmar, Laos, Thailand and Cambodia in the Central South Peninsula are mainly Buddhist. Indonesia, Malaysia and Brunei are mainly Islamic, while the Philippines and East Timor are predominantly 
Catholic. Singapore and Vietnam are characterized by traditional Confucian culture, while more than $70 \%$ of the population of Singapore is Chinese.

\subsubsection{Decentralization and local dynamics}

The specificities of the sociopolitical environment can also be seen in the context of the connection between central and local governments in Southeast Asia. In the era of neoliberalism, most Southeast Asian states experienced significant decentralization, and local governments have been given more independent fiscal rights and decision-making power. Devolution has stimulated local economic initiative but, at the same time, it has resulted in intensified local rivalry because of the legacies of the previous more centrally-controlled economies, as well as in rivalry between central and local authorities (Liu and Dicken, 2006). As a result, local authorities have become major stakeholders in the development of industrial parks, mobilizing regulations and policies to stimulate the development of industrial parks within their jurisdictions. In Malaysia, Vietnam, and other countries local authority control is the greatest in relation to land so that it has played a particularly important role in the development of Chinese industrial parks. Through local policies infrastructure was constructed and the dynamism of the local economic system and local employment increased (Breslin, 2000; Rithmire, 2013; Song et al., 2016).

\subsection{Key actors in formulating policies for Southeast Asian overseas industrial parks}

\subsubsection{National government}

In the era of neoliberalism, the major economic function of national governments was to identify mechanisms supporting the global expansion of capital (Harvey, 2007). Inclusive globalization involves macro-control over capital markets and resource allocation. Macro-control and coordination therefore assume considerable importance in the BRI. More specifically, the BRI emphasizes the importance of policy coordination and the organization of development strategies through planning and programs, which help the participants identify shared interests (Liu, 2017). The establishment of Chinese Southeast Asian overseas industrial parks requires the support of the Chinese and host country governments. First, the two heads of state need to discuss a cooperation agreement. Then, high-level coordination and cooperation committees from the two nations must negotiate and forge cooperation agreements and investment policies. Establishing these committees from both nations strengthens communication on the strategy and project. Through these steps state power plays a vital role in overseas investment. For instance, in 2013, Chinese President Xi Jinping and then-President Susilo of Indonesia jointly witnessed the signing of the contract for the Indonesia Morowali Industrial Park in the China-Indonesia Economic and Trade Cooperation Zone, and the first program in this park. On July 1, 2005, Premier Thaksin of Thailand and Vice Premier Hui Liangyu of China's State Council attended the signing ceremony for the planning the Rayong Thai-China Industrial Park.

\subsubsection{Leading and partner enterprises}

China's leading enterprises are the pioneers of international expansion, and the quest for profits is the primary driving force. In the context of inclusive globalization, leading enterprises have to bear five-connectivity liabilities during the construction of overseas industrial parks. In constructing overseas industrial parks, these leading enterprises strive to expand 
upstream and downstream production and to fully exploit the resources and marketing potential of the host countries. Because Southeast Asia has abundant labor, relatively low labor costs, and enormous market potential, manufacturing sectors attract relatively large amounts of investment. However, leading enterprises also carry many social service responsibilities, such as the development of park infrastructure and services and training the local labor force. Cooperating with enterprises in the host countries is of critical importance, and has been successful: the Thai-China Industrial Park in Rayong was jointly developed by China's Huali Group and Thailand's Amata Group in 2006; the Sihanoukville Special Economic Zone, in the first wave of national overseas economic and trade cooperation zones, was a joint investment by the leader Ormosia Group of Jiangsu Province and many other enterprises from China and Cambodia, and is located in the only international port city in Cambodia; and the Long Giang Industrial Park, a comprehensive industrial park invested in and developed by Tien Giang Investment Management Co. LTD was granted permission to invest in 2007. From an operational perspective, joint ventures established by leading enterprises and host countries are both responsible for daily operations and management. The Indonesia Morowali Industrial Park in the China-Indonesia Economic and Trade Cooperation Zone is owned and managed by Tsingshan Park Development Limited as the owner and manager but developed with two shareholders. The Shanghai Decent Investment Group, a subsidiary of Tsingshan Group has a $66.25 \%$ share and the Indonesia PT Bintangdelapan Group, has a $33.75 \%$ share. In these cooperative agreements between China and Southeast Asian host countries, China's leading enterprises are primarily in charge of designing the park, marketing, international investment promotion, and land development, while the host countries provide land resources for constructing the parks.

\subsubsection{Local governments}

Local governments, as the decentralized organizations of state power in provinces and cities, play a vital role in the smooth construction of overseas industrial parks. Along with central government and national ministries, Chinese local governments are a driving force for constructing overseas industrial parks. Liaoning Province has promoted local enterprises to participate in developing cooperation zones in countries such as Indonesia. The construction of two national cooperation zones, the Thai-China Industrial Park in Rayong and Long Giang Industrial Park, were guided by Zhejiang Province.

In Southeast Asia, national political systems vary, leading to different systems of central-local power. Of the seven authorized countries in the China-Southeast Asia economic and trade cooperation zones: Thailand is a constitutional monarchy; Indonesia is a presidential republic; Laos is a socialist country, and its governing party is the Lao People's Revolutionary Party; Cambodia is a parliamentary constitutional monarchy, but the People's Party has dominated government for many years; Indonesia's government, led by Joko, has applied a series of measures to expand the economy, of which the most important policy was the delegation of central government powers to local governments, increasing their economic freedom, but also increasing the possibility of government rent-seeking and inconsistencies in the economic development guidelines between local provinces and between local and central government. Therefore, in this context, industrial parks must have the support of local government for being successful. Long Giang Industrial Park in Vietnam received substantial support from the governments of China and Vietnam. The Vietnamese Prime Minis- 
ter, Nguyen Tan Dung, personally signed, issued and authorized the allocation of 600 ha of land to the park and introduced the park to Chinese enterprises. The provincial governor, Tien Giang, provided significant support by prioritizing the project, expediting land procedures and providing tax benefits.

\subsubsection{Local residents and non-governmental organizations (NGOs)}

During the construction of overseas industrial parks in Southeast Asia, local labor is fully utilized, creating local employment and enabling local residents to recognize and understand Chinese enterprises. This also helps control labor costs. China's Indonesia Morowali Industrial Park created more than 20,000 direct and about 10,000 indirect jobs for Indonesia. Thus far, more than 10,000 Indonesian employees have been recruited; the associated purchases of more than 5,000 motor bicycles indicates that they have become accustomed to work and life there. In the case of Sihanouk port in Cambodia, 105 enterprises have been admitted to the industrial park with the employment of 16,000 local people in Cambodia. In addition, sustained good relationships with local NGOs and favorable public opinion contribute to the long-term success of overseas industrial parks. Many NGOs in Indonesia positively participate in local non-governmental activities, such as community organizations and agricultural and ecological programs. Concurrently, community development effectively drives the formulation of public policies and drafting of bills.

\subsection{Embeddedness of the mobility of overseas industrial park policies in Southeast Asia}

We have argued that policy formation and transformation are visualized as (socially) constructed processes and are embedded in local environments. China has developed Southeast Asia overseas industrial parks in the light of local conditions in the host countries, while also eventually successfully developing policies combining both features of Chinese industrial parks and local preferential treatment. As Table 3 shows, policy mobility is reflected in the comparability of local and host country policies and a combination of preferential policies and guarantees.

Table 3 General policies for the China-Southeast Asia economic and trade cooperation zones

\begin{tabular}{|c|c|c|}
\hline $\begin{array}{c}\text { Countries in } \\
\text { Southeast Asia }\end{array}$ & $\begin{array}{l}\text { Cooperation } \\
\text { zone }\end{array}$ & Policy \\
\hline Thailand & $\begin{array}{l}\text { Thai-China } \\
\text { Industrial Park } \\
\text { in Rayong }\end{array}$ & $\begin{array}{l}\text { Enterprises with Chinese interest need not pay corporate income tax for a } \\
\text { maximum of } 8 \text { years (different preferences are based on industry; knowl- } \\
\text { edge-based and high-technology industries may secure the maximum tax } \\
\text { free period), imported machinery is tax free for } 8 \text { years; imported materi- } \\
\text { als used for export can be tax exempt for } 5 \text { years; foreign skilled workers, } \\
\text { experts, and their spouses can work; foreign workers can be granted land } \\
\text { ownership. }\end{array}$ \\
\hline Cambodia & $\begin{array}{l}\text { Sihanoukville } \\
\text { Special } \\
\text { Economic } \\
\text { Zone }\end{array}$ & $\begin{array}{l}\text { The Investment Law for the Kingdom of Cambodia stipulates that: in } \\
\text { addition to the stipulation on land ownership mentioned in the constitu- } \\
\text { tion law of the Kingdom of Cambodia, all the investors, regardless of } \\
\text { nationality and race, are equal before the law; nationalization policies that } \\
\text { damage the interests of investors shall not be adopted by the government; in } \\
\text { terms of authorized programs, the government shall not control the product } \\
\text { and service prices; the government shall not carry out foreign exchange } \\
\text { control policies but allow free in-and-out movements of foreign exchange. }\end{array}$ \\
\hline
\end{tabular}

(To be continued on the next page) 
(Continued)

\begin{tabular}{|c|c|c|}
\hline $\begin{array}{c}\text { Countries in } \\
\text { Southeast Asia }\end{array}$ & $\begin{array}{c}\text { Cooperation } \\
\text { zone }\end{array}$ & Policy \\
\hline Cambodia & $\begin{array}{l}\text { Sihanoukville } \\
\text { Special } \\
\text { Economic } \\
\text { Zone }\end{array}$ & $\begin{array}{l}\text { According to the regulations outlined in the Investment Law for the } \\
\text { Kingdom of Cambodia and the management laws for the special districts, } \\
\text { all enterprises in Sihanoukville Special Economic Zone enjoy a series of } \\
\text { preferential tax policies: tax for imported equipment and construction } \\
\text { materials that are used to invest and establish a plant can be } 100 \% \text { exempt } \\
\text { from import tariffs; according to the types of products, enterprises in the } \\
\text { park can have } 6-9 \text { years of generous tax holidays from the business profit } \\
\text { tax; enterprises do not need to pay export tax for exported products; and } \\
\text { equipment and construction materials are free from added-value tax. }\end{array}$ \\
\hline Vietnam & $\begin{array}{l}\text { Long Giang } \\
\text { Industrial Park }\end{array}$ & $\begin{array}{l}\text { The government of Vietnam has already adopted the most preferential tax } \\
\text { policies to attract enterprise investment. Enterprises in the park have a } \\
15 \text {-year tax reduction period once they have operational revenue, with a } \\
\text { discount of } 10 \% \text { (currently, the corporate income tax in Vietnam is } 25 \% \text { ); } \\
\text { before they start to earn money, they also have a } 4 \text {-year tax free period } \\
\text { with a subsequent } 9 \text {-year half-tax period. This is the most preferential set } \\
\text { of tax policies in Vietnam. } \\
\text { Enterprises do not need to pay import and export taxes for equipment } \\
\text { listed in the fixed assets. Once the operation starts, raw materials, goods, } \\
\text { materials, and imported accessories are subject to a } 5 \text {-year import tax free } \\
\text { period. Enterprises in the park can make a decision on the classification of } \\
\text { their enterprise (general enterprise or export processing enterprise) de- } \\
\text { pending on their own situation. Export processing enterprises are free of } \\
\text { import and export taxes and added-value tax for raw materials. }\end{array}$ \\
\hline Indonesia & $\begin{array}{l}\text { China-Indones } \\
\text { ia Economic } \\
\text { and Trade } \\
\text { Cooperation } \\
\text { Zone } \\
\text { Indonesia } \\
\text { Morowali } \\
\text { Industrial Park } \\
\text { China-Indone- } \\
\text { sia Julong } \\
\text { Agricultural } \\
\text { Industry Co- } \\
\text { operation Zone }\end{array}$ & $\begin{array}{l}\text { Enterprises with Chinese interest can enjoy a corporate income tax and } \\
\text { imported machinery tariff free period of up to a maximum of } 8 \text { years. } \\
\text { Enterprises do not need to pay tax for imported raw materials for selling } \\
\text { purposes in the initial } 5 \text { years. Foreign skilled workers, experts, and their } \\
\text { spouses can be brought into the park. Foreign workers can purchase land. } \\
\text { China and Indonesia have signed the Investment Protection Agreement, } \\
\text { Maritime Agreement, Agreement on the Avoidance of Double Taxation } \\
\text { and Memorandum of Understanding for subjects such as agricultural and } \\
\text { mining, which provide guarantees for Chinese enterprise investments in } \\
\text { Indonesia. }\end{array}$ \\
\hline Laos & $\begin{array}{l}\text { Integrated } \\
\text { development } \\
\text { zone of } \\
\text { Saiseta, } \\
\text { Vientiane }\end{array}$ & $\begin{array}{l}\text { The development zone complies with the legal procedures formulated by } \\
\text { the governments of Laos and China. Land use rights can be transferred or } \\
\text { rented to others with a tenure of } 70 \text { years, but can be extended to } 99 \text { years } \\
\text { after expiration with the authorization of the Laos government. } \\
\text { Production enterprises can earn tax free profits for } 6-10 \text { years. Once the } \\
\text { period expires, the enterprises pay } 5 \% \text { tax; commerce and trade enter- } \\
\text { prises have a } 2-5 \text { year profit tax free period, with a subsequent tax rate of } \\
5 \% \text {; service enterprises have a tax free profit period of } 2-10 \text { years, with a } \\
\text { subsequent tax rate of } 5 \% \text {. }\end{array}$ \\
\hline
\end{tabular}

To encourage the international expansion of Chinese enterprises, the Chinese government developed a series of policies. First, both external and internal loans are eligible for interest subsidies. Second, the government provides specific allowances to Chinese enterprises that invest in overseas industrial parks. Even the costs of initial investigations are eligible for 
subsidies. Regarding overseas investment risks, the China Export \& Credit Insurance Corporation provides an interest subsidy of $50 \%$.

Chinese enterprises and overseas companies jointly invest to further develop overseas industrial parks. A management committee is formed to design and implement policy. Overseas industrial parks are subject to the foreign investment laws of the host countries, but enjoy different types of preferential policies in relation to land tax and corporate income tax. Certain types of industrial park enjoy more advanced preferential policies. For example, based on stipulations in Cambodia's special district laws, those who enter Sihanoukville Special Economic Zone enjoy a series of preferential tax policies: enterprises do not need to pay import tariffs for imported equipment or construction materials; according to the types of products, enterprises might enjoy generous 6-9 year tax holidays for business profits; there are no required export taxes; and equipment and construction materials are also exempt from VAT. Malaysia's Multimedia Super Corridor (MSC) is promoted through a set of 'business-friendly' laws. These 'developmental state-type' laws include full exemption from the bumiputera ownership and employment equity laws, no restrictions on employing foreign 'knowledge workers', and major tax concessions (Lepawsky, 2009).

Embeddedness is likely to take other forms when mobilizing policies for overseas industrial parks in Southeast Asia. The key to the sustainable development of overseas industrial parks is discussion and collaboration (in the context of the BRI) and the provision of equal opportunities during construction to ensure that growth is shared. Most Southeast Asian economies are characterized by export-oriented development strategies. Particularly for Laos, Myanmar, and other landlocked developing countries, it is necessary to promote local sustainable development by taking advantage of abundant labor forces, relatively low land costs and preferential tax policies (a key feature of industrial parks in Southeast Asia). Particularly in difficult geopolitical environments, the leading enterprises in overseas industrial parks form a close global production network with global suppliers, taking full advantage of local resources and labor markets (Zhou, 2007).

\subsection{The challenges of policy mobility in relation to Southeast Asia overseas industrial parks}

\subsubsection{Constraints associated with the complicated environment of host countries}

Most Southeast Asian countries are economically less-developed and characterized by complicated geopolitical circumstances. Their socio-economic environments, infrastructure, institutions, and credit systems are immature to different extents, creating difficulties in constructing overseas industrial parks and necessitating policy mobility. For example, in an interview a Chinese director of the Integrated Development Zone in Saiseta, Vientiane indicated that some restrictive characteristics of the Laos's economy including marketing scale and the shortage of management experience, capital and talent meant that some facilities (including external water systems, industrial power, and sewage treatment plants) were still in the design or bidding-stage. The constraints slowed the expansion of enterprises. Moreover, due to the preferential policies (such as special funds for foreign trade and economic activities, concessional loans, preferential tax regimes, preferential bidding arrangements) that governments provide for overseas industrial parks, many domestic enterprises act rashly ignoring potential challenging problems. They also act as an early warning system for 
changes in host country investment conditions, institutions, and policies, which eventually result in losses.

\subsubsection{Pressures deriving from the enterprises-leading investment model}

The enterprises-leading investment model has imposed relatively large financial pressures on enterprises. In contrast to domestic parks, whose infrastructure is supported by the local government, overseas industrial parks have facilities, e.g., water, electricity and gas, financed by independently-raised funds with government assistance. Due to long construction periods and a single profit model associated with the development of land, real estate, public services and service income, the financing channels for overseas industrial parks give rise to deficits. These deficits are offset primarily by banks, e.g., China Development Bank, credit lines, special funds provided by national and local governments, or capital markets. Currently, capital markets are not well-developed, and most is in the form of bond markets. It is difficult for the majority of enterprises to raise money to construct overseas industrial parks using enterprise bonds. Commercial bank cross border credit has not been well-developed. At present, parent company credit lines cannot be directly used by overseas subsidiary corporations, due to problems associated with domestic guarantees for overseas loans and foreign guarantees for overseas loans. Although the government offers fixed subsidies to enterprises in industrial parks, the shortage of capital remains to be fully resolved. The difficulties and the long wait for the recovery of funds result in relatively large capital pressures and investment risks for enterprises.

\subsubsection{Shortage of overseas service platforms embedded in local environment}

In China, there are few service institutions providing information about host country regulations, policies, and customs. In addition, out-of-date information increases investment risks. Although government sectors are engaged in providing many services to internationally expanding enterprises, the amount of local information about detailed programs and operating principles is limited. For instance, during negotiations on key problems, such as land, credit and the recruitment of skilled people, large-scale enterprises playing the leading role still need host country's assistance and authorization. As a result, state-owned enterprises are to some extent advantaged. For example, in the second largest special economic zone in Laos, the Integrated Development Zone of Saiseta, Vientiane, which is led by Chinese state-owned enterprises, the enterprise together with Vientiane's government jointly invests and establishes the development zone. For that reason, the joint venture enterprises are subject to business-friendly policies on taxes and fees, such as a 70-year land use tax waiver. These conditions are particularly advantageous compared with other parks, which suffer from a lack or production localization.

\subsubsection{As yet unformed agglomeration economies in overseas industrial parks}

Even though a set of policies have been successfully developed or transplanted abroad, in the majority of Southeast Asia overseas industrial parks, agglomeration economies are as yet unformed. For example, there are only a few enterprises in the China-Indonesia economic and trade cooperation zones, and their future industrial focus will likely change; at present, the main products are transformers, printing and platemaking, and the assembling of agricultural machinery. Due to this degree of diversity, vertical and horizontal relationships between industries and enterprises are relatively weak. The Integrated Development Zone of 
Saiseta, Vientiane is faced with the same problem. As small and medium-sized enterprises came to form the majority of firms, they have to improve their capital and technical strengths and inter-firm relations, so as to compete with other enterprises.

\section{Conclusions and discussion}

\subsection{Conclusions}

Overseas industrial parks are drivers of inclusive globalization and also an important spatial carrier for the construction of the B\&R. In this paper the central argument is that "policy mobility" is embedded in "places". Local policy makers, NGOs, residents and other participants profoundly influence policy mobility. In this study this argument is developed in relation to the seven Chinese Ministry of Commerce-authorized China-Southeast Asia national overseas economic and trade cooperation zones in an exploration of the processes of the reproducing, transferring, and changing policies from domestic to international industrial parks. Through these efforts, an aim is to encourage political geographers to look beyond the limits of the 'policy mobility' concept and to join more fully in an ongoing conversation involving multiple disciplines in the B\&R research.

In particular, attention was paid to the complex institutional geometries of the host countries for overseas industrial parks in Southeast Asia. The roles and functions of key actors, such as the governments, leading and partner enterprises, local governments, the public, and NGOs during policy implementation were examined. In addition, the current status and challenges of policy assembly with respect to finance and taxation, land, and industry were outlined.

The majority of Chinese overseas industrial parks in Southeast Asia are located in Indonesia, Cambodia, and Thailand, and included manufacturing, labor intensive, and energy resources processing industrial parks. In these seven authorized cooperation zones, the research found that leading enterprises together with their partner enterprises play a dominant role in constructing overseas industrial parks. The governments of the two nations, and especially of the host countries, are crucial to policy mobility. Meanwhile, local governments, the public, and NGOs also have positive effect, facilitating the modification and coordination of public policies for overseas industrial parks.

\subsection{Discussion}

Chinese overseas industrial parks in Southeast Asia wisely use the conditions provided by the host countries and sought to embed themselves fully considering local development conditions. In the light of the evidence derived in this study, the unhindered construction of Chinese B\&R overseas industrial parks would be helped however by the following five policy developments.

(1) Expedite building exclusive international cooperation institutions. China should strengthen coordination between departments for planning and implementing projects at different scales to better plan and manage the construction of overseas industrial parks, and Chinese investment and trade. In this respect it is vital to learn from generally adopted international cooperation strategies developed by European countries and the US, which combine foreign aid, investment, and trade.

(2) Evaluate overseas investment risks to address the complicated and dynamic geo- 
graphic conditions in host countries. Developing relationships with key international organizations and building supportive public opinion, laws, and regulations is an essential component of a solution to these challenges.

(3) Establish an international investment platform and insurance systems. The international expansion of large domestic banks and insurance companies should be supported and facilitated to minimize the risks of overseas investment.

(4) Enhance China's soft power. China should adopt measures to enhance the supportiveness of the civil environment and the advantages of overseas Chinese enterprises in the ASEAN. Making progress in relation to key embeddedness issues including the relationships with local residents and NGOs could accelerate the construction of Chinese overseas industrial parks.

(5) Appreciate the new opportunities associated with the construction of the 21st-Century Maritime Silk Road, and upgrade the China-ASEAN Free Trade Zone and ASEAN Economic Community. China should take advantage of the favorable conditions to explore new cooperation opportunities between China and the ASEAN and increase the benefits of cooperation.

\section{References}

Acemoglu D, Johnson S, Robinson J, 2005. Institutions as the fundamental causes of long-run growth. In: Aghion P, Durlauf S (eds.). Handbook of Economic Growth (North Holland).

Allen J, Cochrane A, 2007. Beyond the territorial fix: Regional assemblages, politics and power. Regional Studies, 41(9): 1161-1175.

Breslin S, 2000. Decentralization, globalization and China's partial re-engagement with the global economy. New Political Economy, 5(2): 205-226.

Cook I, Ward K, 2012. Conferences, informational infrastructures and mobile policies: The process of getting Sweden 'BID ready'. European Urban and Regional Studies, 19(2): 137-152.

England K, Ward K, 2007. Neoliberalization: States, Networks, Peoples. Oxford: Blackwell.

Fraser N, 2003. From discipline to flexibilization? Reading Foucault in the shadow of globalization. Constellations, 10(2): 160-171.

Geddie K, 2015. Policy mobilities in the race for talent: Competitive state strategies in international student mobility. Transactions of the Institute of British Geographers, 40: 235-248.

Harvey D, 2007. A Brief History of Neoliberalism. New York: Oxford University Press.

Hudson R, 2016. Rising powers and the drivers of uneven global development. Area Development and Policy, 1(3): 279-294.

Inverardi-Ferri C, 2017. Variegated geographies of electronic waste: Policy mobility, heterogeneity and neoliberalism. Area Development and Policy, 2(3): 314-331.

Jessop B, Peck J, Tickell A, 1999. Retooling the machine: Economic crisis, state restructuring, and urban politics. In: Jonas A E G, Wilson D (eds.). The Urban Growth Machine: Critical Perspectives Two Decades Later. Albany: State University of New York Press.

Larner W, 2003. “Neoliberalism?”. Environment and Planning D: Society and Space, 21: 509-512.

Larner W, Laurie N, 2010. Travelling technocrats, embodied knowledges: Globalising privatisation in telecoms and water. Geoforum, 41(2): 218-226.

Lepawsky J, 2009. Clustering as anti-politics machine? Situating the politics of regional economic development and Malaysia's multimedia super corridor. Regional Studies, 43(3): 463-478.

Lin G, 2001. Metropolitan development in a transitional socialist economy: Spatial restructuring in the Pearl River Delta, China. Urban Studies, 38(3): 383-406. 
Liu Weidong, 2015. Scientific understanding of the Belt and Road Initiative of China and related research themes. Progress in Geography, 34(5): 538-544. (in Chinese)

Liu Weidong, 2017. The Belt and Road: Leading the Inclusive Globalization. Beijing: The Commercial Press. (in Chinese)

Liu Weidong, Dicken P, 2006. Transnational corporations and 'obligated embeddedness': Foreign direct investment in China's automobile industry. Environment and Planning A, 38: 1229-1247.

Liu Weidong, Michael D, 2016. Inclusive globalization: Unpacking China's Belt and Road Initiative. Area Development and Policy, 1(3): 323-340. doi: 10.1080/23792949.2016.1232598.

Liu Yungang, Ye Qinglu, 2015. Territorialization and territorial politics in the urban grassroots of China. Acta Geographica Sinica, 70(2): 283-296. (in Chinese)

McCann E J, 2004. Urban political economy beyond the 'global' city. Urban Studies, 41: 2315-2333.

McCann E J, 2011. Urban policy mobilities and global circuits of knowledge: Toward a research agenda. Annals of the Association of American Geographers, 101(1): 107-130.

Michael D, 2017. The rise of China and its implications for economics and other developing countries: The significance of the Chinese social model. Area Development and Policy, 2(2): 124-129.

Peck J, Theodore N, 2001. Exporting workfare/importing welfare-to-work: Exploring the politics of third way policy transfer. Political Geography, 20(4): 427-460.

Peck J, Theodore N, 2010. Mobilizing policy: Models, methods, and mutations. Geoforum, 41: 169-174.

Rithmire M, 2013.Land politics and local state capacities: The political economy of urban change in China. The China Quarterly, 216: 872-895.

Shen Ying, 2011. A research on the policy transfer. Academic Forum, (1): 45-47. (in Chinese)

Song Tao, Liu Weidong, Li Le, 2016. International research on the border regions with a geopolitical perspective and revelation. Progress in Geography, 35(3): 276-285. (in Chinese)

Song Tao, Lu Dadao, Liang Yi et al., 2016. Progress in international geopolitical research from 1996 to 2015. Journal of Geographical Sciences, 26(4): 497-512.

Temenos C, McCann E, 2013. Geographies of policy mobilities. Geography Compass, 7(5): 344-357.

Wei Y, 1999. Regional inequality in China. Progress in Human Geography, 23: 48-58.

$\mathrm{Xu}$ J, Yeh A, 2005. City repositioning and competitiveness building in regional development: New development strategies in Guangzhou, China. International Journal of Urban and Regional Research, 29(2): 283-308.

Ye L, 2014. State-led metropolitan governance in China: Making integrated city regions. Cities, 41: 200-208.

Zhang T, 2006. From intercity competition to collaborative planning: The case of Yangtze River Delta region in China. Urban Affairs Review, 42(1): 26-56.

Zhou Y, 2007. The Inside Story of China's High-Tech Industry: Making Silicon Valley in Beijing. Lanham, MD.: Rowman \& Littlefield. 